\title{
Endothelin $\mathrm{ET}_{\mathrm{A}}$ and $\mathrm{ET}_{\mathrm{B}} \mathrm{mRNA}$ and receptors expressed by smooth muscle in the human vasculature: majority of the $\mathrm{ET}_{\mathrm{A}}$ sub-type
}

\author{
'Anthony P. Davenport, Gillian O'Reilly \& Rhoda E. Kuc \\ Clinical Pharmacology Unit, University of Cambridge, Addenbrooke's Hospital, Cambridge CB2 2QQ
}

1 We measured the ratio of $\mathrm{ET}_{\mathrm{A}}$ and $\mathrm{ET}_{\mathrm{B}}$ sub-types in the media (containing mainly smooth muscle) of human cardiac arteries (aorta, pulmonary and coronary), internal mammary arteries and saphenous veins.

2 In saturation experiments, $\left[{ }^{125} \mathrm{I}\right]$-endothelin-1 ([25I]-ET-1) bound with high affinity to the media of each vessel $(n=3$ individuals or homogenate preparations \pm s.e.mean $)$ :coronary artery, $K_{\mathrm{D}}=0.14 \pm 0.02 \mathrm{nM}, B_{\max }=71.0 \pm 21.0 \mathrm{fmol} \mathrm{mg}^{-1}$ protein; pulmonary artery, $K_{\mathrm{D}}=0.85 \pm 0.25 \mathrm{nM}$, $B_{\max }=15.2 \pm 10.3 \mathrm{fmol} \mathrm{mg}{ }^{-1}$ protein; aorta, $K_{\mathrm{D}}=0.51 \pm 0.02 \mathrm{nM}, B_{\max }=9.4 \pm 4.4 \mathrm{fmol} \mathrm{mg}^{-1}$ protein; internal mammary artery, $K_{\mathrm{D}}=0.34 \pm 0.31 \mathrm{nM}, B_{\max }=2.0 \pm 0.5 \mathrm{fmol} \mathrm{mg}^{-1}$ protein and saphenous vein, $K_{\mathrm{D}}=0.28 \pm 0.05 \mathrm{nM}, B_{\max }=52.8 \pm 1.0 \mathrm{fmol} \mathrm{mg}^{-1}$ protein. In each vessel, over the concentration-range tested, Hill slopes were close to unity and a one site fit was preferred to a two site model.

3 In competition binding assays, the $\mathrm{ET}_{\mathrm{A}}$ selective ligand, $\mathrm{BQ} 123$ inhibited the binding of $0.1 \mathrm{nM}$ $\left[{ }^{125} \mathrm{I}\right]-\mathrm{ET}-1$ to the media in a biphasic manner. In each case, a two site fit was preferred to a one or three site model: coronary artery, $K_{\mathrm{D}} \mathrm{ET}_{\mathrm{A}}=0.85 \pm 0.03 \mathrm{nM}, K_{\mathrm{D}} \mathrm{ET}_{\mathrm{B}}=7.58 \pm 2.27 \mu \mathrm{M}$, ratio $=89: 11 \%$; pulmonary artery, $K_{D} \mathrm{ET}_{\mathrm{A}}=0.27 \pm 0.05 \mathrm{nM}, K_{\mathrm{D}} \mathrm{ET}_{\mathrm{B}}=24.60 \pm 5.34 \mu \mathrm{M}$, ratio $=92: 8 \% ;$ aorta, $K_{\mathrm{D}} \mathrm{ET}_{\mathrm{A}}=$ $0.80 \pm 0.40 \mathrm{nM}, K_{\mathrm{D}} \mathrm{ET}_{\mathrm{B}}=2.67 \pm 2.60 \mu \mathrm{M}$ ratio $=89: 11 \%$; saphenous vein, $K_{\mathrm{D}} \mathrm{ET}_{\mathrm{A}}=0.55 \pm 0.17 \mathrm{nM}$, $K_{\mathrm{D}} \mathrm{ET}_{\mathrm{B}}=14.4 \pm 0.26 \mu \mathrm{M}, 85: 15 \%(n=3$ individuals or homogenate preparations \pm s.e.mean $)$. BQ123 showed up to 18000 fold selectivity for the $\mathrm{ET}_{\mathrm{A}}$ over the $\mathrm{ET}_{\mathrm{B}}$ sub-type. The $\mathrm{ET}_{\mathrm{A}}$-selective ligand, $\left[{ }^{125} \mathrm{I}\right]-\mathrm{PD} 151242$ labelled $85 \%$ of the receptors detected by a fixed concentration of $\left[{ }^{125} \mathrm{I}\right]-\mathrm{ET}-1$ in media of internal mammary artery, measured by quantitative autoradiography. In contrast, the density of $\mathrm{ET}_{\mathrm{B}}$

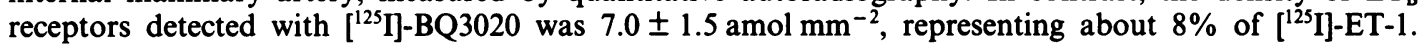
4 A single band corresponding to the expected position for mRNA encoding the ET $_{\mathrm{A}}$ receptor (299 base pairs) was found in the media in each of the five vessels ( $n=3$ individuals) using reversetranscriptase polymerase chain reaction assays. A single band corresponding to the $\mathrm{ET}_{\mathrm{B}}$ sub-type (428 base pairs) was also always detected.

$5{ }^{35} \mathrm{~S}$-labelled antisense probes to $\mathrm{ET}_{\mathrm{A}}$ and $\mathrm{ET}_{\mathrm{B}}$ hybridised to the media of epicardial coronary arteries as well as intramyocardial vessels, confirming the presence of mRNA encoding both sub-types in the vascular smooth muscle of the vessel wall.

6 Although mRNA for both receptors was detected, competition binding using BQ123 demonstrated that the majority (at least $85 \%$ ) of ET receptors present in smooth muscle are the $E_{A}$ sub-type. These results provide further support for the hypothesis that the $\mathrm{ET}_{\mathrm{A}}$ sub-type is the receptor that must be blocked in humans to produce a beneficial vasodilatation in pathophysiological conditions where there is an increase in peptide concentration or receptor density.

Keywords: Endothelin; PD151242; BQ123; BQ3020; ET $_{\mathrm{A}}$ mRNA; ET $_{\mathrm{B}}$ mRNA; autoradiography; polymerase chain reaction; aorta; coronary artery; internal mammary artery; pulmonary artery; saphenous vein

\section{Introduction}

In man, three genes have been predicted to encode three endothelin (ET) peptides, ET-1, ET-2 and ET-3. Biochemical analysis by radioimmunoassay and high performance liquid chromatography has shown that ET-1 and ET-2 are the most abundant isoforms expressed by the human cardiovascular system (Plumpton et al., 1993). ET-1 and ET-2 (but not ET-3) mRNA has been detected in human endothelial cells (O'Reilly et al., 1993a,b). Immunoreactive mature ET, and the precursors big ET-1 and big ET-2 (but not big ET-3) have been localized to the cytoplasm of endothelial cells from a range of human vascular beds including internal mammary artery and saphenous vein (Howard et al., 1992). The widespread distribution of ET-1 (and possibly ET-2) is consistent with a proposed role as a ubiquitous endothelium-derived vasoactive peptide and a corresponding general expression of

' Author for correspondence.
ET receptors in smooth muscle of the vessel wall would be expected. ET-3 is the only endogenous isoform that is able to distinguish between the two receptor sub-types having low affinity for the $\mathrm{ET}_{\mathrm{A}}$ receptor compared to ET-1 but a similar affinity for the $\mathrm{ET}_{\mathrm{B}}$ sub-type. Since ET-3 is a poor agonist at $\mathrm{ET}_{\mathrm{A}}$ receptors, the predominance of this subtype in the smooth muscle of the human vasculature would be consistent with the lack of expression of ET-3 by endothelial cells of blood vessels.

In support of this hypothesis, in isolated epicardial coronary arteries (Davenport et al., 1993) and renal vessels (Maguire et al., 1994b) ET-1-induced vasoconstriction appears to be mediated mainly by the $\mathrm{ET}_{\mathrm{A}}$ sub-type since ET-3 is about two orders of magnitude less potent than ET-1. Secondly, the ET $_{\mathrm{A}}$-selective antagonists cause a rightward and parallel shift of the ET-1-induced constriction in these vessels. However, mRNA encoding both sub-types have been detected and binding assays using sub-type selective ligands suggest $\mathrm{ET}_{\mathrm{B}}$ as well as $\mathrm{ET}_{\mathrm{A}}$ receptors are present. 
In animals, ET-1 can elicit constriction through both $\mathrm{ET}_{\mathrm{A}}$ and $\mathrm{ET}_{\mathrm{B}}$ receptors although the pattern is complex: the subtype ratio varies in different vascular beds in the same species and in the same vascular bed in different species (Davenport \& Maguire, 1994). For example, constriction appears to be mediated only by $\mathrm{ET}_{\mathrm{A}}$ receptors in rat aorta (Sumner et al., 1992) but by $\mathrm{ET}_{\mathrm{B}}$ receptors in rabbit pulmonary artery (White et al., 1994a). In porcine coronary artery, the $\mathrm{ET}_{\mathrm{A}}$ selective antagonist, BQ123 does not block all of the ET-1induced contraction, indicating activation of both sub-types (Ihara et al., 1992).

ET-1 is a potent constrictor of human isolated vessels. The peptide has an $\mathrm{EC}_{50}$ of $15 \mathrm{nM}$ in aorta (Maguire \& Davenport, 1995). In pulmonary arteries, $\mathrm{EC}_{50}$ values have a range of 0.1-17 nM (Hay et al., 1993; Fukuroda et al., 1994; Maguire \& Davenport, 1995) and in coronary arteries the range is $1-130 \mathrm{nM}$ (Franco-Cereceda, 1989; Davenport et al., 1989b; Godfraind et al., 1993; Maguire \& Davenport, 1993; 1994; 1995; Opgaard et al., 1994). In the internal mammary artery, $\mathrm{EC}_{50}$ values range from 4-10 $\mathrm{nM}$ (Costello et al., 1990; Luscher et al., 1990; Bax et al., 1993; Maguire \& Davenport, 1993, 1994; 1995; White et al., 1994b) and 3-18 nM in the sapheneous vein (Luscher et al., 1990; Costello et al., 1990; Maguire \& Davenport, 1993; 1994; 1995; Seo et al., 1994; Akar et al., 1994). However, whether the media of all of these vessels express ET $_{A}$ and ET $_{B}$ mRNA as well as the corresponding receptor protein has not been examined in detail.

Our aim was to use ligand binding to measure the ratio of $\mathrm{ET}_{\mathrm{A}}$ and $\mathrm{ET}_{\mathrm{B}}$ sub-types in the media (containing mainly smooth muscle) of human cardiac arteries where animal studies suggest ET-1 constriction occurs only via $\mathrm{ET}_{\mathrm{A}}$ (rat aorta), $\mathrm{ET}_{\mathrm{B}}$ (rabbit pulmonary artery) or both sub-types (porcine coronary artery). We also compared the internal mammary artery and saphenous veins where $\mathrm{ET}_{\mathrm{B}}$-mediated constrictor responses have been reported (White et al., 1994b; Seo et al., 1994). These results were correlated with the expression of mRNA encoding each receptor using reversetranscriptase polymerase chain reaction (RT-PCR) assays.

\section{Methods}

\section{Vessels}

Aorta, pulmonary arteries, left and right main stem coronary arteries were obtained at the time of operation from male and female patients undergoing heart transplantation (age range 43-56 years) for ischaemic heart disease. Saphenous vein and left internal mammary artery were obtained from male and female patients undergoing coronary artery bypass grafts. The endothelial layer was scraped off and the adventitia separated from the media (confirmed by microscopy of haematoxylin and eosin stained sections). Tissue was snap frozen immediately in liquid nitrogen and stored at $-70^{\circ} \mathrm{C}$ until use.

\section{Saturation binding assays: slide mounted sections}

For ligand binding in larger vessels (aorta, pulmonary and coronary arteries), sections ( $10 \mu \mathrm{m}$ thick) were cut on a cryostat microtome and mounted onto gelatin-coated microscope slides. In saturation experiments, tissue sections were preincubated for $15 \mathrm{~min}$ in HEPES buffer as previously described (Davenport et al., 1989a,b; 1991; Karet \& Davenport, 1993). Briefly, sections were then incubated with increasing concentrations $(8 \mathrm{pM}-8 \mathrm{nM})$ of $\left[{ }^{125} \mathrm{I}\right]-\mathrm{ET}-1$ in incubation buffer for $2 \mathrm{~h}$ at $23^{\circ} \mathrm{C}$. Non-specific binding was defined with $1 \mu \mathrm{M}$ of unlabelled ET-1. Sections were rinsed in Tris- $\mathrm{HCl}$ buffer $(0.05 \mathrm{M}, \mathrm{pH} 7.4)$ at $4^{\circ} \mathrm{C}(3 \times 5 \mathrm{~min})$ and the amount of radioactivity measured in a gamma counter.

\section{Homogenate binding}

Frozen saphenous veins and internal mammary arteries (typically from a minimum of 30 individuals to obtain sufficient tissue) were homogenized in ice cold $50 \mathrm{mM}$ Tris$\mathrm{HCl}$ buffer, pH 7.4 (containing $5 \mathrm{mM} \mathrm{MgCl}_{2}, 5 \mathrm{mM}$ EDTA, $1 \mathrm{mM}$ EGTA, 10,000 units $\mathrm{ml}^{-1}$ aprotinin). The homogenate was centrifuged at $1000 \mathrm{~g}$ for $1 \mathrm{~min}$ at $4^{\circ} \mathrm{C}$, the pellet discarded and the supernatant re-centrifuged at $40,000 \mathrm{~g}$ for $30 \mathrm{~min}$. The resulting pellet was washed and resuspended three times in the Tris- $\mathrm{HCl}$ buffer. The final pellet was resuspended in $50 \mathrm{~mm}$ HEPES buffer, pH 7.4 (containing $5 \mathrm{mM} \mathrm{MgCl}, 0.3 \% \mathrm{wt} / \mathrm{vol}$ bovine serum albumen). After measuring the protein, the membranes were diluted to give typical concentrations of about $6 \mathrm{mg} \mathrm{ml}^{-1}$ protein.

Aliquots $(100 \mu \mathrm{l})$ were added to tubes containing increasing amounts of $\left.{ }^{125} \mathrm{I}\right]-\mathrm{ET}-1(8 \mathrm{pM}-8 \mathrm{nM})$ in HEPES incubation buffer for $2 \mathrm{~h}$ at $23^{\circ} \mathrm{C}$. Non-specific binding was determined with $1 \mu \mathrm{M}$ unlabelled ET-1. The final protein concentration was $2 \mathrm{mg} \mathrm{ml}^{-1}$. Each assay was terminated by centrifugation $\left(20,000 \mathrm{~g}, 10 \mathrm{~min}, 4^{\circ} \mathrm{C}\right)$ to separate bound from free radioligand. The supernatants were discarded and the pellets resuspended in $1 \mathrm{ml}$ ice cold $50 \mathrm{mM}$ Tris- $\mathrm{HCl}$ buffer $(\mathrm{pH} 7.4$ at $\left.4^{\circ} \mathrm{C}\right)$. The tubes were re-centrifuged $(20,000 \mathrm{~g}, 10 \mathrm{~min}$, $4^{\circ} \mathrm{C}$ ), the supernatants discarded and the pellets counted in a gamma counter.

\section{Competition experiments}

Competition assays were carried out under the conditions described above. Sections of aorta, pulmonary and coronary artery or homogenate of saphenous vein were incubated with $0.1 \mathrm{pM}\left[{ }^{125} \mathrm{I}\right]-\mathrm{ET}-1$ and increasing concentrations (20 pM$100 \mu \mathrm{M})$ of $\mathrm{BQ} 123$. Non-specific binding was defined by use of $1 \mu \mathrm{M}$ unlabelled ET-1. The results of binding experiments were analysed with EBDA and LIGAND programmes as previously described (Molenaar et al., 1992; 1993; Davenport et al., 1994a). The presence of 1,2 or 3 sites was tested by the $F$-ratio test in LIGAND. The model adopted was that which provided the best fit $(P<0.05)$.

\section{Autoradiography}

Quantitative autoradiography was used to compare the density of $\mathrm{ET}_{\mathrm{A}}$ and $\mathrm{ET}_{\mathrm{B}}$ receptors in the internal mammary artery, as there was insufficient material for competition binding assays. Sections of internal mammary artery (as well as aorta, pulmonary, coronary arteries and saphenous veins) from three individuals were incubated in buffer containing either $0.1 \mathrm{nM}\left[{ }^{125} \mathrm{I}\right]-\mathrm{ET}-1$ to visualize all ET receptors, $0.1 \mathrm{nM}$ [ $\left.{ }^{125} \mathrm{I}\right]-\mathrm{PD} 151242$ to visualize $\mathrm{ET}_{\mathrm{A}}$ (Davenport et al., 1994a,c; Peter \& Davenport, 1994; 1995) or $0.1 \mathrm{nM}\left[{ }^{125} \mathrm{I}\right]-\mathrm{BQ} 3020$ (Molenaar et al., 1992; 1993) to detect the $\mathrm{ET}_{\mathrm{B}}$ sub-type. [125I]-PD151242 has previously been shown to be highly selective for the human $\mathrm{ET}_{\mathrm{A}}$ sub-type and the unlabelled compound is a competitive antagonist causing a parallel rightward shift of the ET-1 concentration-response curve in human isolated coronary arteries (Davenport et al., 1994a). $\left[{ }^{125} \mathrm{I}\right]-\mathrm{BQ} 3020$ is selective for the human $\mathrm{ET}_{\mathrm{B}}$ sub-type (Molenaar et al., 1992; 1993) and a potent agonist at animal $\mathrm{ET}_{\mathrm{B}}$ receptors (Gardiner et al., 1994). In each case, nonspecific binding was determined by incubating adjacent consecutive sections in the presence of $1 \mu \mathrm{M}$ of the corresponding unlabelled peptides. Sections were exposed to radiationsensitive film (Hyperfilm $\beta$ max) with radioactive standards and quantified by computer-assisted densitometry as previously described (Davenport et al., 1988).

\section{Reverse-transcriptase polymerase chain reaction ( $R T$-PCR) assays}

Total RNA was extracted from the media of aorta, pulmonary, coronary, internal mammary arteries and saphenous 
veins from three individuals by a single step guanidinium isothiocyanate method. cDNA synthesis and RT-PCR assays were carried out as previously described (O'Reilly et al., 1992; 1993a,b; Karet et al., 1994). Avian myoblastosis virus reverse transcriptase was used to synthesize first strand cDNA from $2.5 \mu \mathrm{g}$ RNA. Nested PCR amplification was carried out using $1 \mu \mathrm{l}$ cDNA template, $5 \mu \mathrm{l}$ reaction buffer $\left(100 \mathrm{nM}\right.$ Tris- $\mathrm{HCl}, \mathrm{pH} 8.3$ at $25^{\circ} \mathrm{C}, 500 \mathrm{mM} \mathrm{KCl}$ and $15 \mathrm{~mm}$ $\left.\mathrm{MgCl}_{2}\right), 5 \mu \mathrm{ldNTPs}(2 \mathrm{mM}), 5 \mu \mathrm{l}$ of each of the appropriate oligonucleotide primer pairs (designed from published nucleotide sequences) and 2.5 U Taq DNA polymerase. PCR products were separated by agarose gel electrophoresis and the bands stained with ethidium bromide. These previously cloned and sequenced PCR products show $100 \%$ homology with published sequences for $\mathrm{ET}_{\mathrm{A}}$ or $\mathrm{ET}_{\mathrm{B}}\left(\mathrm{O}^{\prime}\right.$ Reilly et al., 1992).

\section{In situ hybridization}

The distribution of $\mathrm{ET}_{\mathrm{A}}$ and $\mathrm{ET}_{\mathrm{B}}$ mRNA was compared in more detail in coronary arteries by in situ hybridization. Assays were carried out as previously described (Molenaar $e t$ al., 1993). Briefly, $\mathrm{ET}_{\mathrm{A}}$ (bases 439-737) and $\mathrm{ET}_{\mathrm{B}}$ (bases 497-924) PCR amplified DNA bands were cloned into pBluescript II KS (Stratagene Inc., La Jolla, California, U.S.A.) and the linearised inserts used as a template to generate ${ }^{35} \mathrm{~S}$ labelled sense and antisense RNA probes. Sections of epicardial coronary artery and intra-ventricular septum containing intra-myocardial vessels were exposed to radiation-sensitive film together with standards. The amount of probe specifically hybridized was determined by digitally subtracting the autoradiographical image of the sense control probe from that of the antisense probe by computer-assisted densitometry as previously described (Davenport \& Nunez, 1990).

Table 1 Dissociation constants $\left(K_{\mathrm{D}}\right)$, maximal density of receptors $\left(B_{\max }\right)$ and Hill coefficients $\left(\mathrm{n}_{\mathrm{H}}\right)$ for $\left[{ }^{125} \mathrm{I}\right]$-endothelin-1 ([25I]-ET-1) binding in human vessels

$\begin{array}{ccc} & \mathrm{B}_{\max } & \\ \mathrm{K}_{D} & \left(\mathrm{fmol} \mathrm{mg}^{-1}\right. & \\ (\mathrm{nM}) & \text { protein) } & n_{H}\end{array}$

Arteries:

Coronary

Pulmonary

Aorta

Internal mammary

Vein:

Saphenous
$0.14 \pm 0.02$

$0.85 \pm 0.25$

$0.51 \pm 0.02$

$0.34 \pm 0.31$

$0.28 \pm 0.05$
$71.0 \pm 21.0$

$15.2 \pm 10.3$

$9.4 \pm 4.4$

$0.99 \pm 0.01$

$0.85 \pm 0.08$

$0.85 \pm 0.11$

$0.92 \pm 0.10$

$52.8 \pm 1.0$

$0.89 \pm 0.01$
For aorta, coronary and pulmonary arteries values are the mean \pm s.e.mean of three individuals; for saphenous vein and internal mammary artery values are the mean \pm s.e.mean of three separate experiments using vessels pooled from about 30 individuals.
Drugs

BQ123, (cyclo [D-Asp-L-Pro-D-Val-L-Leu-D-Trp-], Ihara et al., 1992) and BQ3020, [Ala $\left.{ }^{11,15}\right]$ Ac-ET-1(6-21) (Molenaar et al., 1992) were synthesized by solid phase t-Boc chemistry. PD151242, (N-[(hexahydro-1-azepinyl)carbonyl]L-Leu(1-Me) D-Trp-D-Tyr (Davenport et al., 1994a,c) was synthesized and supplied by Dr A.M. Doherty (Parke-Davis Pharmaceutical Research Division). Peptide concentrations were determined by u.v. spectrophotometry. $\left[{ }^{125} \mathrm{I}\right]-\mathrm{ET}-1,\left[{ }^{125} \mathrm{I}\right]-\mathrm{PD} 151242$ and $\left[{ }^{125} \mathrm{I}\right]-\mathrm{BQ} 3020$ were from Amersham International plc, (Amersham, UK); unlabelled ET-1 from Novabiochem (Nottingham, UK). Taq polymerase was from Perkin-Elmer Cetus (London, UK), reverse-transcriptase from Anglian Biotech (Essex, UK). All other reagents were from Sigma Chemical Co. (Poole, Dorset, UK), BDH (Poole, Dorset, UK) or Fisons (Loughborough, Leicester, UK).

\section{Results}

\section{Ligand binding}

$\left[{ }^{125} \mathrm{I}\right]-\mathrm{ET}-1$ bound with a similar sub-nanomolar affinity to the media of all of the vessels examined (Table 1). In each vessel, over the concentration-range tested, Hill slopes were close to unity and a one site fit was preferred to a two site model. The highest densities of ET receptors were present in the coronary arteries; lowest levels were detected in the internal mammary artery.

BQ123 competed for the binding of a fixed concentration of [ $\left.{ }^{125} \mathrm{I}\right]-\mathrm{ET}-1$ in a biphasic manner in the media of all vessels (Table 2, Figure 1). In each case, a one site model could not be fitted to these data and a two site fit was preferred to a three site model, giving a high nanomolar affinity corresponding to the $\mathrm{ET}_{\mathrm{A}}$ receptor and a low, micromolar site corresponding to the $\mathrm{ET}_{\mathrm{B}}$ receptor. $\mathrm{BQ} 123$ showed up to 18000 fold selectivity for the $\mathrm{ET}_{\mathrm{A}}$ over the $\mathrm{ET}_{\mathrm{B}}$ sub-type. In each case $\mathrm{ET}_{\mathrm{A}}$ receptors predominated, with the $\mathrm{ET}_{\mathrm{B}}$ subtype representing less than $15 \%$ of the ET receptors in smooth muscle cells of the human vasculature.

\section{Autoradiography}

Owing to the small size of internal mammary arteries obtained following surgery it was not possible to obtain sufficient receptor protein to carry out competition assays and relative densities were compared by quantitative autoradiography. The density of $\mathrm{ET}_{\mathrm{A}}$ binding in the media of internal mammary artery following incubation with a fixed concentration of $\left.{ }^{[25} \mathrm{I}\right]-\mathrm{PD} 151242$ was $78.7 \pm 5.9 \mathrm{amol} \mathrm{mm}^{-2}$, representing about $85 \%$ of the $\left[{ }^{125} \mathrm{I}\right]-\mathrm{ET}-1$ binding $(92.9 \pm$ $4.6 \mathrm{amol} \mathrm{mm} \mathrm{mm}^{-2}$ ). In contrast, the density of $\mathrm{ET}_{\mathrm{B}}$ receptors detected with $\left[{ }^{125} \mathrm{I}\right]-\mathrm{BQ} 3020$ was $7.0 \pm 1.5 \mathrm{amol} \mathrm{m^{-2 }}$, representing about $8 \%$ of $\left[{ }^{125} \mathrm{I}\right]-\mathrm{ET}-1$. As expected from the competition binding assays, a similar pattern was observed in the media from aorta, pulmonary and coronary arteries as well

Table 2 Inhibition of $\left[{ }^{125} \mathrm{I}\right]$-endothelin-1 $\left.\left({ }^{125} \mathrm{I}\right]-\mathrm{ET}-1\right)$ binding to media from human vessels by the $\mathrm{ET}_{\mathrm{A}}$ selective $\mathrm{BQ} 123$

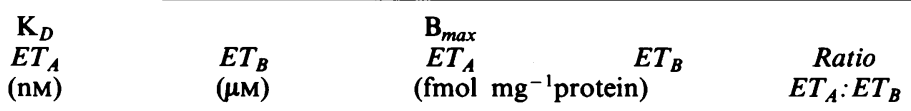

$\begin{array}{lrrrrl}\text { Arteries: } & & & & & \\ \text { Coronary } & 0.85 \pm 0.03 & 7.58 \pm 2.27 & 15.4 \pm 4.1 & 1.7 \pm 0.5 & 89: 11 \\ \text { Pulmonary } & 0.27 \pm 0.05 & 24.60 \pm 5.34 & 27.2 \pm 3.0 & 2.4 \pm 0.6 & 92: 8 \\ \text { Aorta } & 0.80 \pm 0.40 & 2.67 \pm 2.60 & 9.4 \pm 1.7 & 1.1 \pm 0.4 & 89: 11 \\ \text { Vein: } & & & & & \\ \text { Saphenous } & 0.55 \pm 0.17 & 14.4 \pm 0.26 & 35.3 \pm 20.2 & 6.5 \pm 1.5 & 85: 15\end{array}$

Values are mean \pm s.e.mean of 3 individuals. 

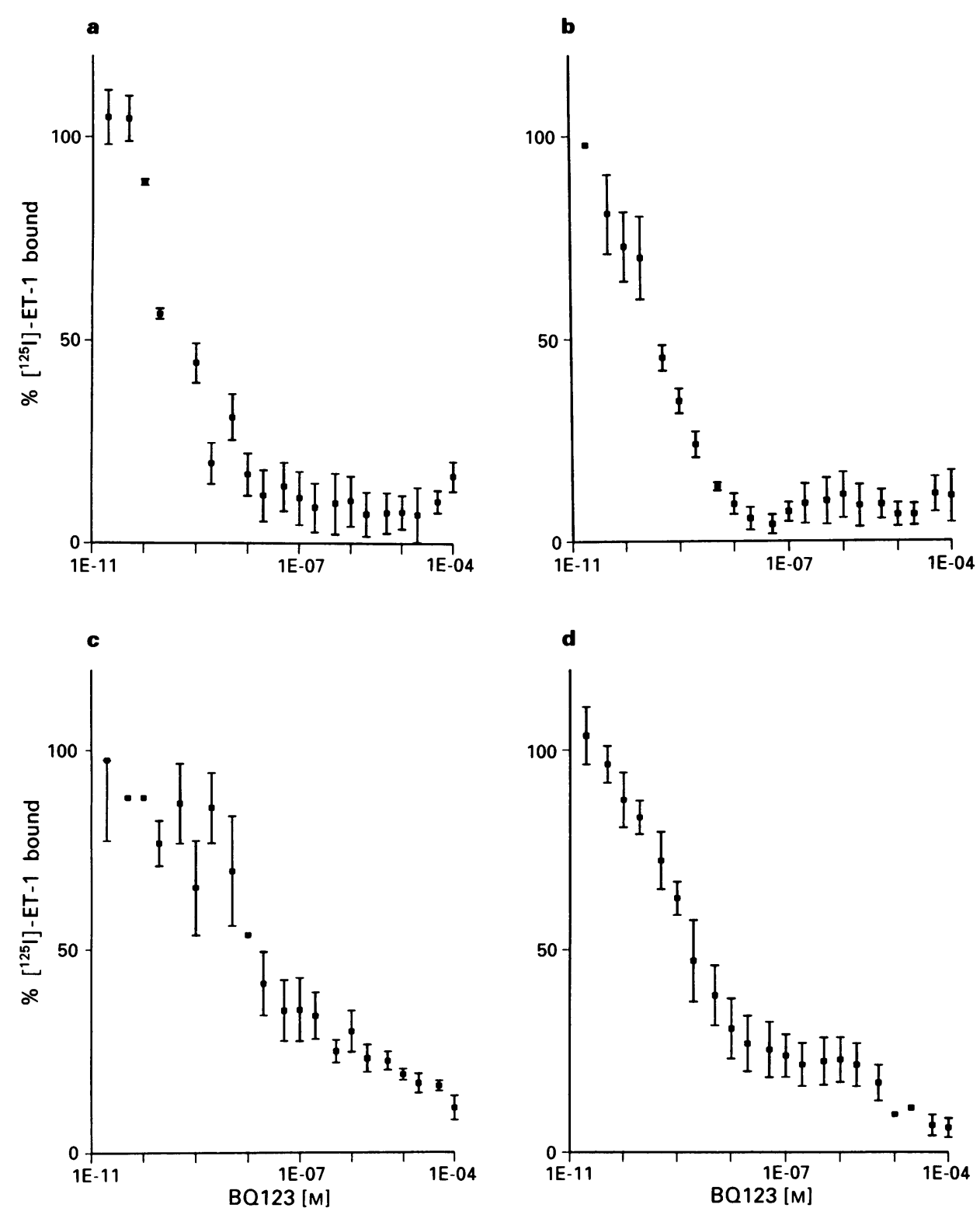

Figure 1 Inhibition of $0.1 \mathrm{nM}$ [125] ${ }^{12}$-endothelin-1 ([25I]-ET-1) binding by BQ123 to slide mounted sections of main stem aorta (a), pulmonary artery (b), coronary artery (c) and saphenous vein (d). In each case, with the exception of the aorta, over the concentration-range tested, BQ123 competed in a biphasic manner and a two site fit was preferred to a one site or three site model. (Each value represents the mean \pm s.e.mean of three individuals except for saphenous vein where homogenates were prepared from about 30 vessels).

as the saphenous vein, with the density of $\mathrm{ET}_{\mathrm{B}}$ receptors being much lower in the smooth muscle than densities of the $\mathrm{ET}_{\mathrm{A}}$ sub-type localized by [ $\left.{ }^{125} \mathrm{I}\right]-\mathrm{PD} 151242$.

\section{Molecular biology}

Agarose gels showing the presence of PCR products of the expected size corresponding to mRNA encoding both the $\mathrm{ET}_{\mathrm{A}}$ receptor (299 base pairs) and $\mathrm{ET}_{\mathrm{B}}$ receptor (428 bases pairs) were detected in the media obtained from three individuals in each of the four arteries and saphenous vein. Bands were not detected in the negative control lane in which the template had been omitted (Figure 2).

\section{In situ hybridization}

The ${ }^{35}$ S-labelled antisense ET $_{A}$ probe hybridized to the media of epicardial coronary arteries as well as intramyocardial vessels. The autoradiographic image of the sense control probe was digitally subtracted from that of the antisense probe to give the amount specifically hybridized of $90 \pm$ $8 \mathrm{amol} \mathrm{mm}^{-2}$ in epicardial coronary arteries and $50.0 \pm$ $3 \mathrm{amol} \mathrm{mm^{-2 }}$ in intramyocardial vessels (mean \pm s.e.mean of at least 3 vessels). The amount of non-specific hybridization detected by the sense control probe was higher for the $\mathrm{ET}_{\mathrm{B}}$ receptor but specific hybridization could still be detected, $34.3 \pm 3 \mathrm{amol} \mathrm{mm} \mathrm{mol}^{-2}$ and $43.0 \pm 8 \mathrm{amol} \mathrm{mm} \mathrm{mm}^{-2}$ in epicardial and intra-myocardial vessels respectively.

\section{Discussion}

$\left.{ }^{125} \mathrm{I}\right]-\mathrm{ET}-1$ bound with a similar sub-nanomolar affinity to the media containing mainly vascular smooth muscle, in all of the human blood vessels examined. Over the concentrationrange tested, Hill slopes were close to unity and a one site fit was preferred to a two site model. These results suggest the presence of either a single population of receptors or a 

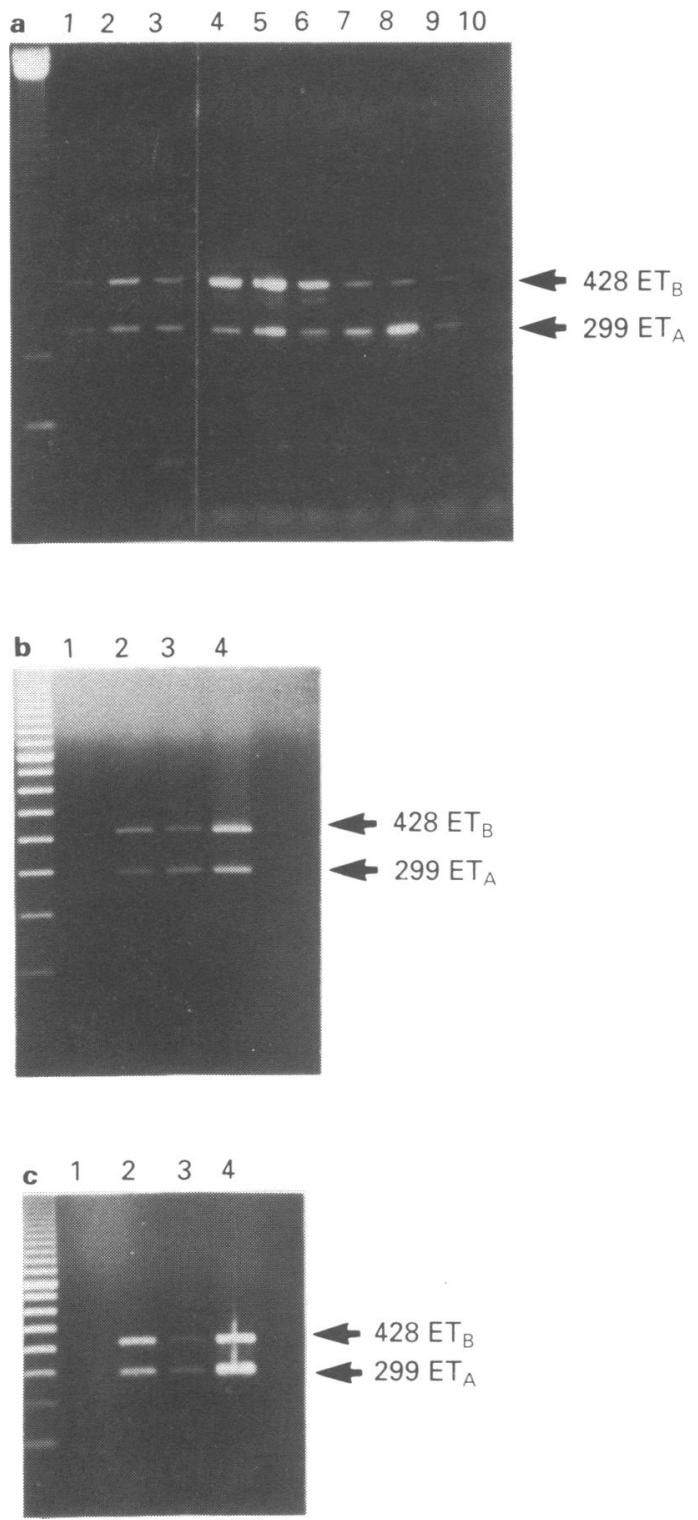

Figure 2 Detection of $\mathrm{ET}_{\mathrm{A}}$ and $\mathrm{ET}_{\mathrm{B}} \mathrm{mRNA}$ in human vessels. Agarose gel electrophoresis of reverse-transcriptase polymerase chain reaction (RT-PCR) products from the media (containing mainly vascular smooth muscle cells) of vessels obtained from different vascular beds. The presence of PCR bands corresponding to size predicted for $\mathrm{ET}_{\mathrm{A}}$ (299 base pairs) and $\mathrm{ET}_{\mathrm{B}}$ ( 428 base pairs) mRNA was detected in the media of all vessels examined. (a) Lane 1-3, aorta from three individuals; lane 4-6, pulmonary artery from three individuals; lane 7-9, coronary artery from three individuals. Lane 10 , negative control where cDNA template had been omitted. The marker is a 123-base pair ladder. (b) Lane 1, negative control where cDNA template had been omitted. Lane $2-4$, saphenous vein from three individuals. The marker is a 100-base pair ladder. (c) Lane 1, negative control where cDNA template had been omitted. Lane 2-4, internal mammary artery from three individuals. The marker is a 100-base pair ladder.

heterogeneous population with the same affinity for the peptide. In the majority of human tissues examined using homogenates or slide mounted sections, labelled ET-1 binds monophasically with affinities ranging from about $0.01-$ $10 \mathrm{nM}$, with receptor densities of about 10 to $10000 \mathrm{fmol}$ $\mathrm{mg}^{-1}$ protein (Davenport et al., 1994d). The range of $K_{\mathrm{D}}$ values in the media of these five vessels $(0.14-0.85 \mathrm{nM})$ compare with values estimated by the same technique in other types of human muscle. For example, in human myometrium (consisting of mainly non-vascular smooth muscle), $K_{\mathrm{D}}$ values were $1.2 \mathrm{nM}$ (Bacon et al., 1993). In cardiac muscle, $K_{\mathrm{D}}$ values of 0.60 and $0.35 \mathrm{nM}$ were obtained in atria and ventricle (Molenaar et al., 1993). The range of affinities for $\left[{ }^{125} \mathrm{I}\right]-$ ET-1 binding to homogenates of placental arteries and veins (presumed to contain media, adventitia and endothelium) was 0.026-0.045 nM (Robaut et al., 1991). Thus [ $\left.{ }^{125} \mathrm{I}\right]-\mathrm{ET}-1$ binds with high affinity in the media of these vessels although the density of binding is comparatively low compared to other human tissue. The affinities calculated by ligand binding for the five vessels show a positive correlation with the $\mathrm{EC}_{50}$ values for the contractile effects of this peptide on the isolated vessels denuded of endothelium (Maguire \& Davenport, 1995).

A consistent pattern emerged with the detection in all vessels of receptor mRNA using RT-PCR. A single PCR product corresponding to the expected position for $E_{A}$ mRNA was detected in media of each of these vessels. A single band corresponding to $\mathrm{ET}_{B}$ mRNA was also always found. Localization of $\mathbf{E T}_{B}$ as well as $\mathrm{ET}_{\mathrm{A}}$ mRNA to vascular smooth muscle cells was confirmed by in situ hybridization in sections of coronary arteries. Single bands corresponding to $\mathrm{ET}_{\mathrm{A}}$ and $\mathrm{ET}_{\mathrm{B}} \mathrm{mRNA}$ have also been found in renal veins and arteries by RT-PCR (Maguire et al., 1994b) and by Northern analysis in internal mammary artery (Seo et al., 1994). Expression of mRNA encoding both sub-types has been found in a range of human tissues including ventricle (Molenaar et al., 1993), endometrium (O'Reilly et al., 1992) and kidney (Davenport et al., 1993b). In these studies, detection of mRNA correlates with expression of receptor protein. Using the same RT-PCR assay conditions with isolated cells, only $\mathrm{ET}_{\mathrm{B}}$ mRNA was detected in human vascular endothelial cells whereas rat aortic smooth muscle cells express $\mathrm{ET}_{\mathrm{A}}$ mRNA (Molenaar et al., 1993) and only the $\mathrm{ET}_{\mathrm{A}}$ receptor protein could be detected (Davenport et al., 1994b). However, in isolated myocytes mRNA encoding both sub-types was found and BQ123 inhibited binding of iodinated ET-1 biphasically, confirming that both receptor sub-types were present in these cells (Molenaar et al., 1993).

The $\mathrm{ET}_{\mathrm{A}}$ selective ligand, $\mathrm{BQ} 123$, inhibited $\left[{ }^{125} \mathrm{I}\right]-\mathrm{ET}-1$ binding in a biphasic manner in both arteries (aorta, pulmonary and coronary arteries) as well as saphenous vein in agreement with the molecular biology studies. Quantitative autoradiography showed that while a small population of $\mathrm{ET}_{\mathrm{B}}$ receptors could be detected in the internal mammary artery, the $\mathrm{ET}_{\mathrm{A}}$ sub-type was again more abundant. Similar results have been obtained with other human vessels. In human kidney, $\mathrm{ET}_{\mathrm{A}}$ receptors detected with $\left[{ }^{125} \mathrm{I}\right]-\mathrm{PD} 151242$ were mainly localized to the vasculature and microautoradiography demonstrated smaller vessels such as arterioles expressed the $\mathrm{ET}_{\mathrm{A}}$ sub-type (Karet et al., 1993).

$\mathrm{BQ} 123$ competes for $\left[{ }^{125} \mathrm{I}\right]-\mathrm{ET}-1$ binding for an $\mathrm{ET}_{\mathrm{A}}$ site in the nanomolar range and $\mathrm{ET}_{\mathrm{B}}$ site at micromolar concentrations in a number of human tissues including cardiac muscle (Molenaar et al., 1993), myometrium (Bacon et al., 1993) and kidney cortex and medulla (Karet et al., 1993). Intriguingly, Bax et al. (1993) found while BQ123 competed in a biphasic manner for $\left[{ }^{125} \mathrm{I}\right]-\mathrm{ET}-1$ binding in human cardiac muscle the compound detected only one site in coronary arteries. Two sites were detected when BQ123 competed for $\left[{ }^{125} \mathrm{I}\right]$-sarafotoxin $\mathrm{S} 6 \mathrm{~b}$ in this artery. This was interpreted as evidence of a non-ET $\mathrm{A}_{\mathrm{A}} / \mathrm{ET}_{\mathrm{B}}$ site. The RT-PCR assays used in this study have not revealed the presence of additional bands. In competition binding assys, BQ123 competed with similar affinities in coronary artery as all other vessels where Schild slopes of unity have also been found (Maguire \& Davenport, 1995).

These studies show that human vessels express a small population of $\mathrm{ET}_{\mathrm{B}}$ receptors. In animals, a complex pattern of ET-1-induced vasoconstriction has emerged, with a significant $\mathrm{ET}_{\mathrm{B}}$ component in some vessels (see for example, Davis et al., 1991; Clozel et al., 1992; Sumner et al., 1992; Cristol et al., 1993; Gardiner et al., 1994; Pollock \& Opgenorth, 1993; 1994; Wellings et al., 1994; White et al., 1994a) whereas constriction appears to be mediated only by $\mathrm{ET}_{\mathrm{A}}$ receptors in rat aorta (Sumner et al., 1992) or rabbit 
renal artery (Telemarque et al., 1993) but both sub-types are activated in porcine coronary artery (Ihara et al., 1992).

Although the $\mathrm{ET}_{\mathrm{B}}$ agonists $\mathrm{BQ} 3020$ and $\left[\mathrm{Ala}^{1,3,11,15}\right]$-ET-1 are potent constrictors of some rat vascular beds (Bigaud \& Pelton, 1992; Gardiner et al., 1994), they had no detectable action on the isolated vessels used in this study at concentrations up to $3 \mu \mathrm{M}$ (Davenport et al., 1993; Maguire \& Davenport, 1995). The non-endogenous $\mathrm{ET}_{\mathrm{B}}$ agonist in mammals, sarafotoxin S6c, was also inactive in aorta and pulmonary artery (Maguire \& Davenport, 1995). This peptide does cause vasoconstriction in some human vessels such as saphenous vein (White et al., 1994b, Maguire \& Davenport, 1995), internal mammary artery (Seo et al., 1994; Maguire \& Davenport, 1995) and vein (Seo et al., 1994), omental arteries and veins (Riezebos et al., 1994) and pulmonary arteries (Hay et al., 1993; Maguire \& Davenport, 1995). Where responses did occur, these can be variable, for example a response was detected in saphenous vein in only about $50 \%$ (White et al., 1994) of individuals or less (Maguire \& Davenport, 1995). Although the constrictor actions of this snake venom are potent, the magnitude of the response is much less than that of ET-1. Therefore whilst some individuals may have functional constrictor $\mathrm{ET}_{\mathrm{B}}$ receptors, the poor response to ET-3 in these vessels (Maguire \& Davenport, 1994, Davenport \& Maguire, 1995) would suggest that these receptors may have limited physiological importance in the cardiovascular system.

Ligand binding has demonstrated that the majority (at least $85 \%$ ) of ET receptors present in smooth muscle from the five vessels are of the $\mathrm{ET}_{\mathrm{A}}$ sub-type. Functional studies have shown that $\mathrm{ET}_{\mathrm{A}}$-selective antagonists in these vessels cause a parallel, rightward shift of the ET-1 concentrationresponse curve and Schild slopes were not significantly different from unity (Maguire \& Davenport, 1995; Maguire et al., 1994a,c). This contrasts with porcine coronary artery, where a portion of the ET-1 response mediated via presumed $\mathrm{ET}_{\mathrm{B}}$ receptors is not blocked by BQ123 (Ihara et al., 1992).

In other human vessels, ET-1 is always more potent, with the ET-3 dose-response curve shifted to the right. ET-3 is at least 100 fold less potent that ET-1 in omental veins (Riezebos et al., 1994), renal arteries and veins (Maguire et al., 1994b), umbilical artery (Bodelsson \& Stjernquist, 1993) or inactive in omental arteries (Riezebos et al., 1994). Where full concentration-response curves have been carried out comparing ET-1 and ET-3, human vessels have not yet been identified in which ET-3 is equipotent to ET-1 as in the rabbit pulmonary artery (White et al., 1994a).

In the human vasculature, a consistent pattern is emerging: although both receptors can be detected by ligand binding, in vitro pharmacological experiments suggest that vasoconstriction in man is mediated predominantly via the $\mathrm{ET}_{\mathrm{A}}$ sub-type. Taken together, these results provide further support for the hypothesis that the $\mathrm{ET}_{\mathrm{A}}$ sub-type is the receptor that must be blocked in human patients to produce a beneficial vasodilatation in pathophysiological conditions where there are elevated concentrations of the peptide or increases in receptor density. $\mathrm{ET}_{\mathrm{A}}$ selective drugs may have an additional advantage in avoiding blockade of the $E_{B}$ sub-type present on endothelial cells since activation of these receptors by ET-1 is thought to release endothelium-derived relaxing factors.

We thank the surgeons and theatre staff of Papworth Hospital for their co-operation in obtaining tissue and Dr A.M. Doherty (ParkeDavis Pharmaceutical Research Division) for synthesizing and supplying PD151242. Supported by grants from the British Heart Foundation, Royal Society, BBSRC, Isaac Newton Trust.

\section{References}

AKAR, F. UYDES, B.S., AYRANCIOGLU, K., YENER, A., ASLAMACI, S., ARSAN, M., TORUNER, A. \& KANZIK, I. (1994). Endothelial function of human gastroepiploic artery in comparison with saphenous vein. Cardiovasc. Res., 28, 500-504.

BACON, C.R., O'REILLY, G., CAMERON, I.T. \& DAVENPORT, A.P. (1993). Endothelin receptors in human myometrium characterized by BQ123 and BQ3020. Br. J. Pharmacol., 110, P45.

BAX, W.A., BRUINVELS, A.T., VAN-SUYLEN, R.J., SAXENA, P.R. \& HOYER, D. (1993). Endothelin receptors in the human coronary artery, ventricle and atrium. A quantitative autoradiographic analysis. Naunyn-Schmied. Arch. Pharmacol., 348, 403-410.

BIGAUD, M. \& PELTON, J.T. (1992). Discrimination between ET A $^{-}$ and $\mathrm{ET}_{\mathrm{B}}$-receptor mediated effects of endothelin-1 and $\left[\text { Ala }{ }^{1,3,11,15}\right]_{\text {endothelin-1 }}$ by BQ123 in the anaesthetised rat. $\mathrm{Br} . \mathrm{J}$. Pharmacol., 107, 912-917.

BODELSSON, G. \& STJERNQUIST, M. (1993). Characterization of endothelin receptors and localization of 125I-endothelin-1 binding sites in human umbilical artery. Eur. J. Pharmacol., 249, $299-305$.

CLOZEL, M., GRAY, G.A., BREU, V., LÖFFLET, B.-M. \& OSTERWALDER, R. (1992). The endothelin ET $_{B}$ receptor mediates both vasodilation and vasoconstriction in vivo. Biochem. Biophys. Res. Commun., 186, 867-873.

COSTELLO, K.B. STEWART, D.J. \& BAFFOUR, R. (1990). Endothelin is a potent constrictor of human vessels used in coronary revascularization surgery. Eur. J. Pharmacol., 186, 311-314.

CRISTOL, J.P., WARNER, T.D., THIEMERMANN, C. \& VANE, J.R. (1993). Mediation via different receptors of the vasoconstrictor effects of endothelins and sarafotoxins in the systemic circulation and renal vasculature of the anaesthetised rat. Br. J. Pharmacol., $108,776-779$.

DAVENPORT, A.P., BERESFORD, I.J.M., HALL, M.D., HILL, R.G. \& HUGHES, J. (1988). Quantitative autoradiography. In Molecular Neuroanatomy, Vol. III, pp. $121-145$ ed. Van Leeuwen, F.W., Buijs, R.M., Pool, C.W. \& Pach, O. Amsterdam: Elsevier.

DAVENPORT, A., KUC, R.E., FITZGERALD, F., MAGUIRE, J.J., BERRYMAN, K. \& DOHERTY, A.M. (1994a). [ ${ }^{125}$ I]-PD151242: a selective radioligand for human $\mathrm{ET}_{\mathrm{A}}$ receptors. Br. J. Pharmacol., 111, 4-6.
DAVENPORT, A.P., KUC, R.E., HOSKINS, S.L., KARET, F.E. \& FITZGERALD, F. (1994b). [ $\left.{ }^{125} \mathrm{I}\right]$-PD151242 is selective for endothelin $\mathrm{ET}_{\mathrm{A}}$ receptors in human kidney and localises to renal vasculature. Br. J. Pharmacol., 113, 1303-1310.

DAVENPORT, A.P., KUC, R.E., HOSKINS, S.L. \& KARET, F.E. (1994c). $\left[{ }^{125} \mathrm{I}\right]-\mathrm{PD} 151242$ is a selective endothelin $\mathrm{ET}_{\mathrm{A}}$ receptors in human kidney and localises to the vasculature. Br. J. Pharmacol., 112, 554P.

DAVENPORT, A.P. \& MAGUIRE, J.J. (1994). Is endothelin-induced vasoconstriction mediated only by $\mathrm{ET}_{\mathrm{A}}$ receptors in humans? Trends Pharmacol. Sci., 15, 9-11.

DAVENPORT, A.P., MAGUIRE, J.J. \& KARET, F.E. (1994d). Endothelin receptors and their subtypes. In Endothelin: Role in Health and Disease. ed. A. Gulati, pp. 13-23. Amsterdam: Harwood Academic Publishers.

DAVENPORT, A.P., MORTON, A.J. \& BROWN, M.J. (1991). Localisation of endothelin $(1-3)$, mouse VIC and sarafotoxin S6b binding sites in mammalian heart and kidney. J. Cardiovasc. Pharmacol., 17,7, S152-S155

DAVENPORT, A.P. \& NUNEZ, D.J. (1990). Quantification in in situ hybridisation. In In Situ Hybridization ed. Polak, J.M. \& McGee, J.O.D. pp. 95-111. Oxford: Oxford University Press

DAVENPORT, A.P., NUNEZ, D.J. \& BROWN, M.J. (1989a). Quantitative autoradiography reveals binding sites for [125I] endothelin-1 in kidneys with a differential distribution among rat, pig and man. Clin. Sci., 77, 129-131.

DAVENPORT, A.P., NUNEZ, D.J., HALL, J.A, KAUMANN, A.J. \& BROWN, M.J. (1989b). Autoradiographical localisation of binding sites for [125I] endothelin-1 in humans, pigs and rats: functional relevance in man. J. Cardiovasc. Pharmacol., 13,5, S166-170.

DAVENPORT, A.P., O'REILlY, G., MOLENAAR, P., MAGUIRE, J.J., KUC, R.E., SHARKEY, A., BACON, C.R. \& FERRO, A. (1993). Human endothelin receptors characterised using reverse transcriptase-polymerase chain reaction, in situ hybridization and sub-type selective ligands BQ123 and BQ3020: evidence for expression of $\mathrm{ET}_{\mathrm{B}}$ receptors in human vascular smooth muscle. $J$. Cardiovasc. Pharmacol., 22(S8), 22-25. 
DAVIS, L.S., LADOUCEUR, D.M., KEISER, J.A. \& HALEEN, S.J. (1991). Relative vasodilator and vasoconstrictor activity of endothelin-1 (ET-1), endothelin-3 (ET-3) and sarafotoxin 6c (SFTX-6c) on regional arterial beds of the anaesthetized rat: relationship to $\mathrm{ET}_{\mathrm{A}}$ and $\mathrm{ET}_{\mathrm{B}}$ receptor agonist activity. FASEB $J$., 6, 391.

FRANCO-CERECEDA, A. (1989). Endothelin- and neuropeptide Yinduced vasoconstriction of human epicardial coronary arteries in vitro. Br. J. Pharmacol., 97, 968-972.

FUKURODA, T., KOBAYASHI, M., OZAKI, S., YANO, M., MIYAUCHI, T., ONIZUKA, M., SUGISHITA, Y., GOTO, K. \& NISHIKIBE, M. (1994). Endothelin receptor subtypes in human versus rabbit pulmonary arteries. J. Appl. Physiol., 76, 1976-1982.

GARDINER, S.M., KEMP, P.A., MARCH, J.E., BENNETT, T., DAVENPORT, A.P. \& EDVINSSON, L. (1994). Effects of an $\mathrm{ET}_{1}$-receptor antagonist, FR139317 on regional haemodynamic responses to endothelin-1 and $\left[\mathrm{Ala}^{11,15}\right]$ Ac-endothelin-1 (6-21) in conscious rats. Br. J. Pharmacol., 112, 477-486.

GODFRAIND, T. (1993). Evidence for heterogeneity of endothelin receptor distribution in human coronary artery. Br. J. Pharmacol., 110, 1201-1205.

HAY, D.W.P., LUTTMANN, M.A., HUBBARD, W.C. \& UNDEM, B.J. (1993). Endothelin receptor subtypes in human and guinea-pig pulmonary tissues. Br.J. Pharmacol., 110, 1175-1183.

HOWARD, P.G., PLUMPTON, C. \& DAVENPORT, A.P. (1992), Anatomical localisation and pharmacological activity of mature endothelins and their precursors in human vascular tissue. $J$. Hypertens, 10, 1379-1386.

IHARA, M., NOGUCHI, K., SAEKI, T., FUKURODA, T., TSUCHIDA S., KIMURA, S., FUKAMI, T., ISHIKAWA, K., NISHIKIBE, M. \& YANO, M. (1992). Biological profiles of highly potent novel endothelin antagonists selective for the ETA receptor. Life Sci. 50, 247-255.

KARET, F.E. \& DAVENPORT, A.P. (1993). Human kidney: Endothelin isoforms revealed by HPLC with radioimmunoassay, and receptor sub-types detected using ligands BQ123 and BQ3020. J. Cardiovasc. Pharmacol., 22(S8), 29-33.

KARET, F.E., JONES, D.S.C., HARRISON-WOOLRYCH, M., O'REILLY, G.R., DAVENPORT, A.P. \& SMITH, S.K. (1994). Validation of mRNA quantification using a novel fluorescent nested reverse transcriptase polymerase chain reaction. Anal. Biochem., 220, $384-390$.

KARET, F.E., KUC, R.E. \& DAVENPORT, A.P. (1993). Novel ligands $B Q 123$ and $B Q 3020$ characterize endothelin receptor subtypes $\mathrm{ET}_{\mathrm{A}}$ and $\mathrm{ET}_{\mathrm{B}}$ in human kidney. Kidney Int., 44, 36-42.

LUSCHER, T.F., YANG, Z., BAUER, E., TSCHUDI, M., VON-SEGESSER, L., STULZ, P., BOULANGER, C., SIEBENMANN, R., TURINA, M. \& BUHLER, F.R. (1990). Interaction between endothelin-1 and endothelium-derived relaxing factor in human arteries and veins. Circ. Res., 66, 1088-1094.

MAGUIRE, J.J., BACON, C.R., FUIJIMOTO, M. \& DAVENPORT, A.P. (1994a). Myricerone caffeoyl ester 50-235, is a non-peptide antagonist selective for human $\mathrm{ET}_{\mathrm{A}}$ receptors. J. Hypertens., 12, 675-680.

MAGUIRE, J.J. \& DAVENPORT, A.P. (1993). Endothelin-induced vasoconstriction in human isolated vasculature is mediated predominantly via activation of $\mathrm{ET}_{\mathrm{A}}$ receptors. Br. J. Pharmacol. 110, P47.

MAGUIRE, J.J. \& DAVENPORT, A.P. (1994). Pre-administration or post-administration of BQ123 and FR129317 antagonizes endothelin-1 (ET-1)-induced contraction of human blood vessels in vitro. Br. J. Pharmacol., 111, P149.

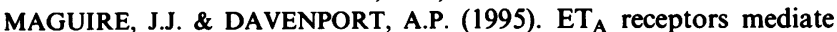
the constrictor responses to endothelin peptides in human blood vessels in vitro. Br. J. Pharmacol. (in press).

MAGUIRE, J.J., KUC, R.E., O'REILLY, G. \& DAVENPORT, A.P. (1994b). Vasoconstrictor endothelin receptors characterised in human renal artery and vein in vitro. Br.J. Pharmacol., 113, 49-54.

MAGUIRE, J.J., KUC, R.E., O'REILLY, G. \& DAVENPORT, A.P. (1994c). Potency of the novel orally active antagonist Ro46-2005 for endothelin receptors in human vascular smooth muscle. Br. $J$. Pharmacol., 112, 552P.

MOLENAAR, P., KUC, R.E. \& DAVENPORT, A.P. (1992). Characterization of two new $\mathrm{ET}_{\mathrm{B}}$ selective radioligands. $\left.{ }^{125} \mathrm{I}\right]-\mathrm{BQ} 3020$ and $\left[{ }^{125} \mathrm{I}\right]-\left[\mathrm{Ala}{ }^{1,3,11,15}\right]-\mathrm{ET}-1$ in human heart. Br. J. Pharmacol., 107, $637-639$.
MOLENAAR, P., O'REILLY, G., SHARKEY, A., KUC, R.E., HARDING D.P., PLUMPTON, P., GRESHAM, G.A. \& DAVENPORT, A.P. (1993). Characterization and localization of endothelium receptor sub-types in the human atrioventricular conducting system and myocardium. Circ. Res., 72, 526-538.

OPGAARD, O.S., ADNER, M., GULBENKIAN, S. \& EDVINSSON, L. (1994). Localization of endothelin immunoreactivity and demonstration of constrictory endothelin-A receptors in human coronary arteries and veins. J. Cardiovasc. Pharmacol., 23, 576-583.

O'REILLY, G., CHARNOCK-JONES, D.S., CAMERON, I.T., SMITH, S.K. \& DAVENPORT, A.P. (1993a). Endothelin-2 mRNA splice variants detected by RT-PCR in cultured human vascular smooth muscle and endothelial cells. J. Cardiovasc. Pharmacol., 22 (S8), $18-21$.

O'REILLY, G., CHARNOCK-JONES, D.S., DAVENPORT, A.P., CAMERON, I.T. \& SMITH, S.K. (1992). Presence of mRNA for endothelin-1, endothelin-2, and endothelin-3 in human endometrium, and a change in the ratio of $\mathrm{ET}_{\mathrm{A}}$ and $\mathrm{ET}_{\mathrm{B}}$ receptor subtype across the menstrual cycle. J. Clin. Endocrinol. Metab., $75,1545-1549$.

O'REILLY, G., CHARNOCK-JONES, D.S., MORRISON, J.J., CAMERON, I.T., DAVENPORT, A.P. \& SMITH, S.K. (1993a,b). Alternatively spliced mRNAs for human endothelin-2 and their tissue distribution. Biochem. Biophys. Res. Commun., 193, 834-840.

PETER, M.G. \& DAVENPORT, A.P. (1994). [ ${ }^{125}$ I]-PD151242 as an endothelin $\mathrm{ET}_{\mathrm{A}}$ selective radioligand in the human, rat and porcine heart. Br. J. Pharmacol., 112, 494P.

PETER, M.G. \& DAVENPORT, A.P. (1995). Selectivity of [ ${ }^{125}$ I]-PD 151242 for the human, rat and porcine endothelin $\mathrm{ET}_{\mathrm{A}}$ receptors in the heart. Br. J. Pharmacol., 114, 297-302.

PLUMPTON, C., CHAMPENEY, R., ASHBY, M.J., KUC, R.E. \& DAVENPORT, A.P. (1993). Characterisation of endothelin isoforms in human heart: Endothelin 2 demonstrated. J. Cardiovasc. Pharmacol., 22 (S8), 26-28.

POLLOCK, D.M. \& OPGENORTH, J. (1993). Evidence for endothelininduced renal vasoconstriction independent of $\mathrm{ET}_{\mathrm{A}}$ receptor activation. Am. J. Physiol., 264, R222-R226.

POLLOCK, D.M. \& OPGENORTH, J. (1994). ET receptor-mediated responses to endothelin-1 and big endothelin-1 in the rat kidney. Br. J. Pharmacol., 111, 729-732.

RIEZEBOS, J., WATTS, I.S. \& VALLANCE, P.J.T. (1994). Endothelin receptors mediating functional responses in human small arteries and veins. Br. J. Pharmacol., 111, 609-615.

ROBAUT, C., MONDON, F., BANDET, J., FERRE, F. \& CAVERO, I. (1991). Regional distribution and pharmacological characterization of [ ${ }^{125}$ I] endothelin-1 binding sites in human fetal placental vessels. Placenta, 12, 55-67.

SEO, B., OEMAR, B.S., SIEBENMANN, R., VON-SEGESSER, L. \& LUSCHER, T.F. (1994). Both ET(A) and ET(B) receptors mediate contraction to endothelin-1 in human blood vessels. Circulation, 89, $1203-1208$.

SUMNER, M.J., CANNON, T.R., GARRATT, H., MUNDIN, J.W., WHITE, D.G. \& WATTS, I.S. (1992). Endothelin ET(A) and ET(B) receptors mediate vascular smooth muscle contraction. Br. J. Pharmacol., 107, 858-860.

TELEMAQUE, S., GRATTON, J.-P., CLAING, A. \& D'ORLEANS-JUSTE, P. (1993). Endothelin-1 induces vasoconstriction and prostacyclin release via the activation of endothelin $\mathrm{ET}_{\mathrm{A}}$ receptors in the perfused rabbit kidney. Eur. J. Pharmacol., 237, 275-281.

WELLINGS, R.P., CORDER, R. WARNER, T.D., CRISTOL, J.-P., THIEMERMANN, C. \& VANE, J.R. (1994). Evidence from receptor antagonists for an important role for $\mathrm{ET}_{\mathrm{B}}$-mediated vasoconstrictor effects of endothelin-1 in the rat kidney. Br. J. Pharmacol., 111, $515-520$.

WHITE, D.G., CANNON, T.R., GARRATT, H., MUNDIN, J.W., SUMNER, M.J. \& WATTS, I.S. (1994a). Endothelin ET A $_{\text {and }}$ ET receptors mediate vascular smooth-muscle contraction. J. Cardiovasc. Pharmacol., 22, S144-S148.

WHITE, D.G., GARRATT, H., MUNDIN, J.W., SUMNER, M.J., VALLANCE, P.J. \& WATTS, I.S. (1994b). Human saphenous vein contains both endothelin ET(A) and ET(B) contractile receptors. Eur. J. Pharmacol., 257, 307-310.

(Received August 3, 1994 Revised November 9, 1994 Accepted November 10, 1994) 